\title{
Sodium Chloroacetate Modified Polyethyleneimine/Trimesic Acid Nanofiltration Membrane to Improve Antifouling Performance
}

\author{
Kaifeng Gu, Sichen Pang, Yong Zhou * $\mathbb{D}$ and Congjie Gao
}

Citation: Gu, K.; Pang, S.; Zhou, Y.; Gao, C. Sodium Chloroacetate Modified Polyethyleneimine/ Trimesic Acid Nanofiltration Membrane to Improve Antifouling Performance. Membranes 2021, 11, 705. https: / / doi.org/10.3390/

membranes11090705

Academic Editors:

Alexandra Pulyalina,

Galina Polotskaya and

Valeriia Rostovtseva

Received: 11 August 2021

Accepted: 6 September 2021

Published: 14 September 2021

Publisher's Note: MDPI stays neutral with regard to jurisdictional claims in published maps and institutional affiliations.

Copyright: (c) 2021 by the authors. Licensee MDPI, Basel, Switzerland. This article is an open access article distributed under the terms and conditions of the Creative Commons Attribution (CC BY) license (https:/ / creativecommons.org/licenses/by/ $4.0 /)$.
Center for Membrane and Water Science \& Technology, Zhejiang University of Technology, Hangzhou 310014, China; 2111701057@zjut.edu.cn (K.G.); pangsc1229@126.com (S.P.); gaocj@zjut.edu.cn (C.G.)

* Correspondence: zhouy@zjut.edu.cn

\begin{abstract}
Nanofiltration (NF) is a separation technology with broad application prospects. Membrane fouling is an important bottleneck-restricting technology development. In the past, we prepared a positively charged polyethyleneimine/trimesic acid (PEI/TMA) NF membrane with excellent performance. Inevitably, it also faces poor resistance to protein contamination. Improving the antifouling ability of the PEI/TMA membrane can be achieved by considering the hydrophilicity and chargeability of the membrane surface. In this work, sodium chloroacetate $\left(\mathrm{ClCH}_{2} \mathrm{COONa}\right)$ is used as a modifier and is grafted onto the membrane surface. Additionally, $0.5 \% \mathrm{ClCH}_{2} \mathrm{COONa}$ and $10 \mathrm{~h}$ modification time are the best conditions. Compared with the original membrane (M0, 17.2 $\mathrm{L} \mathrm{m}^{-2} \mathrm{~h}^{-1}$ ), the initial flux of the modified membrane (M0-e, $30 \mathrm{~L} \mathrm{~m}^{-2} \mathrm{~h}^{-1}$ ) was effectively increased. After filtering the bovine albumin (BSA) solution, the original membrane flux dropped by $47 \%$ and the modified membrane dropped by $6.2 \%$. The modification greatly improved the antipollution performance of the PEI/TMA membrane.
\end{abstract}

Keywords: nanofiltration; sodium chloroacetate; modification; antipollution performance

\section{Introduction}

Nanofiltration (NF) membranes have seen huge developments in the past few decades [1-4]. There are many materials used as NF membranes, including polysulfone (PSF) [5], polyethersulfone (PES) [6], polyamide (PA) [7], polyimide (PI) [8], etc. The membrane structure can be symmetrical or asymmetrical. Commercial NF membranes have been widely produced and applied to some substance purification and separation links. As an advanced separation technology, the treatment effect of NF membranes is excellent, but some aspects still need improvement. The problem of membrane fouling in some complex systems is a concern of many researchers [9-12]. Recently, many new antipollution NF membrane studies have been reported. Wang et al. prepared an automated PENF membrane surface with a millimeter-size pattern to improve membrane performance [13]. Chen et al. adopted an in situ photo-grafting strategy to graft the bactericidal polyhexamethylene biguanide and hydrophilic polyethylene glycol onto the polyamide membrane surface. The resulting composite membrane showed great antibacterial and antifouling performance [14]. Membrane fouling will reduce the permeate flux and worsen the effluent quality. The cost of process operation will increase substantially as a result, which greatly limits the application of NF membranes. Although some chemical cleaning methods can be used to solve the problem of membrane fouling, it will inevitably increase operating costs and reduce work efficiency. Moreover, the membrane structure may be damaged and reduce the service life.

There are many reasons for the formation of membrane fouling, such as scale, suspended particles, and organic matter adsorption [15-17]. Especially for NF membranes, researching the pollution process is difficult due to its complex separation mechanism. 
For example, the surface of the NF membrane can be charged, uncharged, positively charged, or negatively charged [18-20]. This means that many filter media (protein or other polyelectrolytes) may become the main source of pollution. Many related studies have been carried out to improve the antifouling ability of membranes. Surface modification is a relatively common antifouling strategy for NF membranes [21,22]. Under physical or chemical action, some special materials can be grafted onto the membrane surface. The interface characteristics (hydrophilicity and chargeability, etc.) of the membrane surface are therefore changed. In this way, many studies have successfully improved the antifouling ability of PA, graphene oxide (GO), cellulose, NF membranes, etc. [23-27].

Polyethyleneimine (PEI) has become an ideal material for preparing NF membranes due to its excellent film-forming properties and high chargeability. Usually, the surface of the PEI NF membrane is positively charged and it has a high removal capacity for multivalent cations. In the past, we prepared positively charged PEI/TMA NF membranes with excellent performance [28]. In the separation of salt solutions, the PEI/TMA membrane showed great selectivity and permeability, but in the antipollution experiment of protein, the membrane flux dropped drastically in a short period of time. The hydrophilicity and chargeability of the membrane surface led to this result. In this work, sodium chloroacetate $\left(\mathrm{ClCH}_{2} \mathrm{COONa}\right)$ was grafted to the PEI/TMA membrane surface to improve the antifouling ability. The hydrophilicity of the membrane was improved and the positive charge was weakened slightly. The PEI/TMA membrane flux was improved and the BSA adsorption phenomenon was greatly alleviated.

\section{Experiments}

\subsection{Materials}

These chemical reagents were provided by Aladdin (Shanghai, China), including polyethyleneimine (PEI, Mw $=70,000,50 \%$ solution), trimesic acid (TMA, AR, 98\%), sodium chloroacetate $\left(\mathrm{ClCH}_{2} \mathrm{COONa}, \mathrm{AR}, \geq 98 \%\right)$, sodium laurylsulfonate (SDS, $\left.\mathrm{AR}, 98 \%\right)$, and bovine serum albumin (BSA, Biotech, $96 \%$ ). Magnesium chloride $\left(\mathrm{MgCl}_{2}\right.$, powder, $\left.\geq 99 \%\right)$, sodium chloride $(\mathrm{NaCl}, \mathrm{AR}, 99.5 \%)$, magnesium sulphate $\left(\mathrm{MgSO}_{4}, \mathrm{AR}, \geq 98 \%\right)$, sodium sulphate $\left(\mathrm{Na}_{2} \mathrm{SO}_{4}, \mathrm{AR}, \geq 99 \%\right)$, and anhydrous ethanol (AR, $\left.\geq 99.7 \%\right)$ were purchased from China National Pharmaceutical Group Corporation. $\mathrm{NaOH}(\geq 96 \%)$ and $\mathrm{HCl}$ (AR, $36 \% \sim 38 \%$ ), purchased from Sigma-Aldrich (Shanghai, China), were used to adjust the $\mathrm{pH}$ of the feed liquid. Polyethersulfone ultrafiltration membrane (PES, MWCO 30,000 40,000 Da), provided by Huzhou Research Institute, was used as the base material of the composite membrane.

\subsection{Membrane Preparation and Modification}

The PEI/TMA NF membrane was prepared by a gradient cross-linking process [28,29]. The TMA cross-linking agent solution infiltrated the PES membrane surface, which can cross-link the PEI solution to form a separation layer. The preparation details can be found in previous research [28]. Here, the membrane, prepared with parameters of $1.0 \%$ PEI, $0.1 \%$ TMA, cross-linking temperature of $90^{\circ} \mathrm{C}$, and a heating time of $10 \mathrm{~min}$, was marked as $\mathrm{M} 0$. The membrane $\mathrm{M} 0$ was immersed in the $\mathrm{ClCH}_{2} \mathrm{COONa}$ aqueous solution. The modification process is shown in Figure 1. The M0 membranes immersed with $0.1 \%, 0.2 \%$, $0.3 \%, 0.4 \%$, and $0.5 \% \mathrm{ClCH}_{2} \mathrm{COONa}$ aqueous solutions for $2 \mathrm{~h}$ were marked as $\mathrm{M} 0-1, \mathrm{M} 0-2$, M0-3, M0-4, and M0-5. The M0 membranes immersed with $0.5 \% \mathrm{ClCH}_{2} \mathrm{COONa}$ aqueous solution for $2 \mathrm{~h}, 4 \mathrm{~h}, 6 \mathrm{~h}, 8 \mathrm{~h}$, and $10 \mathrm{~h}$ were marked as M0-a, M0-b, M0-c, M0-d, M0-e. $\mathrm{ClCH}_{2} \mathrm{COONa}$ was easily ionized under the action of static electricity and the $\mathrm{ClCH}_{2} \mathrm{COO}^{-}$ could be successfully grafted to the surface of the membrane. 


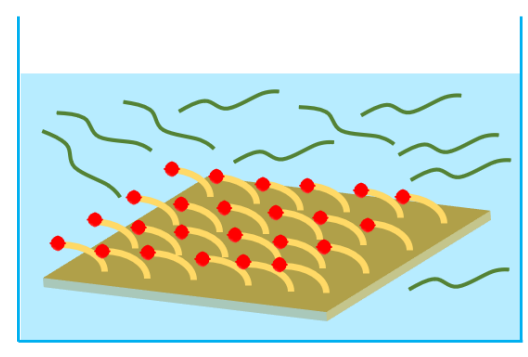

PEI/TMA membrane

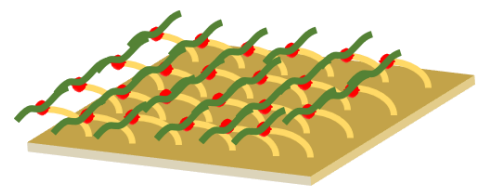

modified membrane surface

\section{$:-\mathrm{NH}_{3}^{+} \sim: \mathrm{ClCH}_{2} \mathrm{COONa}$}

Figure 1. The process of $\mathrm{ClCH}_{2} \mathrm{COONa}$ modifying a PEI/TMA membrane.

\subsection{Characterization}

The membrane surface morphology could be observed by field emission scanning electron microscopy (FE-SEM, Hitachi Limited, SU8010, Tokyo, Japan). Before observation, the membrane surface was sputtered with nano-platinum gold by an ion sputtering instrument. Atomic force microscopy (AFM, BRUKER, Dimension Icon, Los Angeles, $\mathrm{CA}$, America) was used to analyze the surface roughness of the membrane. In tapping mode, the cantilever scanned above the sample in air. Due to the interaction between the sample and the cantilever, the cantilever swung in the vertical direction, and the surface morphology of the sample was reflected. The hydrophilicity of the membrane surface was measured by a contact angle tester (OCA50AF, Data physics, Filderstadt, Germany). Before the test, the membrane was smoothly pasted on the glass slide with double-sided tape. An amount of $1 \mu \mathrm{L}$ of deionized water touched the membrane surface lightly, and the dynamic changes of the droplets were recorded by the camera. The membrane surface potential was obtained by a solid surface zeta potential analyzer (SurPASS, Anton Paar GmbH, Graz, Austria). The $\mathrm{pH}$ of the test system was adjusted by $0.1 \mathrm{~mol} / \mathrm{L} \mathrm{NaOH}$ and $\mathrm{HCl}$ solutions. A conductivity meter (DDSJ-308A, Shanghai, China) was used to evaluate the concentration of a single salt solution.

\subsection{Membrane Performance Evaluation}

The evaluation of membrane performance mainly focused on selectivity and permeability. The membrane was encapsulated in a cell with a $0.00196 \mathrm{~m}^{2}$ effective filtration area and tested by cross-flow filtration. The membrane was pre-pressed at 2 bar for $1 \mathrm{~h}$ before testing, and then membrane performance was evaluated at $2 \mathrm{bar}$. The test system was controlled at room temperature. The permeate flux was calculated by the formula $\mathrm{F}=\mathrm{V} /(\mathrm{A} \times \Delta \mathrm{t}), \mathrm{V}(\mathrm{L})$ was the permeate volume, $\mathrm{A}\left(\mathrm{m}^{2}\right)$ is the effective filtration area, and $\Delta \mathrm{t}$ is the filtration time. The solute rejection was calculated by the formula $\mathrm{R}=\left(1-\mathrm{C}_{\mathrm{p}} / \mathrm{C}_{\mathrm{f}}\right) \times 100 \%, \mathrm{C}_{\mathrm{p}}$ is the permeate concentration, and $\mathrm{C}_{\mathrm{f}}$ is the feed liquid concentration. The concentration of a single salt solution could be replaced by conductivity. The flux drop rate $\left(\mathrm{F}_{\mathrm{r}}\right)$ was defined by flux after filtering for $80 \mathrm{~min}\left(\mathrm{~F}_{\mathrm{p}}\right)$ and initial flux $\left(\mathrm{F}_{0}\right)$. It was calculated by the formula $\mathrm{F}_{\mathrm{r}}=\left(1-\frac{\mathrm{F}_{\mathrm{p}}}{\mathrm{F}_{0}}\right) \times 100 \%$.

\section{Results and discussion}

\subsection{Membrane Surface Morphology Analysis}

The original membrane (M0) and the modified membranes' (M0-1-M0-5) SEM images were observed at $10 \mathrm{kV}$ voltage. The surface morphology of the membrane had hardly changed (Figure 2), which was due to the fact that $\mathrm{ClCH}_{2} \mathrm{COONa}$ is a small molecule substance and the membrane pores might not have changed (Supplementary Information, SI, Figure S1) during the modification process. The basic structure of the membrane had not changed. It could be considered that the composite membrane was still intact after modification. In addition, the modification could not change the surface roughness (Figure 3, 
Table 1). The undulating valley ridge structure encouraged some organic molecules to accumulate in the valley [30,31], and this accumulation was difficult to wash away. A smooth membrane surface was conducive to slow the formation of the cake layer. The modification failed to achieve results in this respect, which means that protein adsorption still existed.
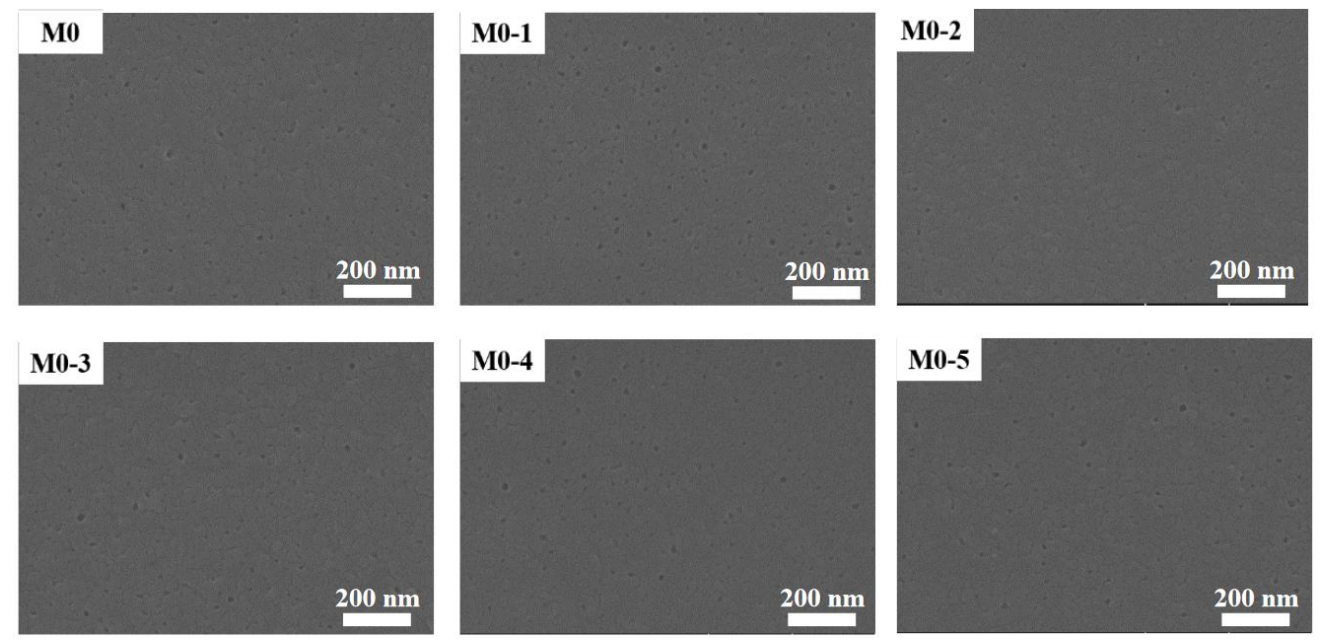

Figure 2. Comparison of membrane surface morphology before and after $\mathrm{ClCH}_{2} \mathrm{COONa}$ modification .
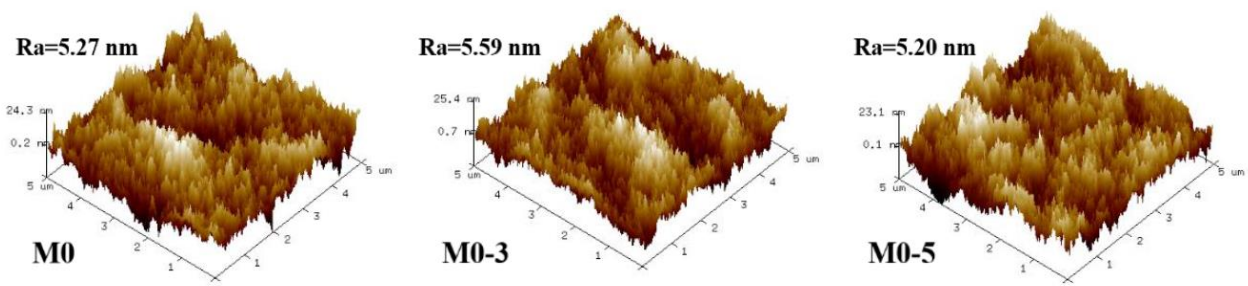

Figure 3. Original membrane and surface roughness (height unit: $\mathrm{nm}$ ).

Table 1. Membrane roughness.

\begin{tabular}{ccc}
\hline Membrane & $\mathbf{R}_{\mathbf{q}}(\mathbf{n m})$ & $\mathbf{R}_{\mathbf{a}}(\mathbf{n m})$ \\
\hline M0 & 6.71 & 5.27 \\
M0-3 & 7.02 & 5.29 \\
M0-5 & 6.52 & 5.20 \\
\hline
\end{tabular}

\subsection{Membrane Interface Characteristics}

Although the physical morphology of the surface had not changed, the hydrophilicity could be significantly affected. In the static contact angle analysis, with the extension of the $\mathrm{ClCH}_{2} \mathrm{COONa}$ concentration and modification time, the water contact angle decreased significantly (Figure 4). The wettability of water molecules on the membrane surface was improved. It could be believed that the highly hydrophilic membrane surface could improve the antifouling performance [32,33]. The hydrophilic area made it easy to form a dense hydration layer on the membrane surface, which weakened the adsorption of pollutants during the filtration process. 
(a)

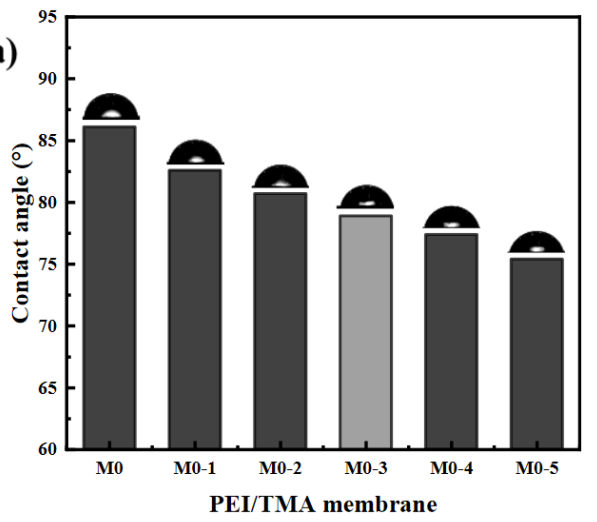

(b)

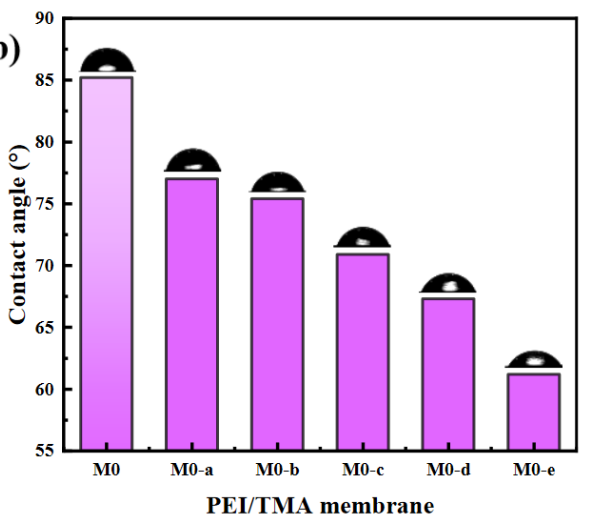

Figure 4. The influence of $\mathrm{ClCH}_{2} \mathrm{COONa}$ concentration (a) and modification time (b) on the hydrophilicity of the membrane surface.

The reduced contact angle indicated that the $\mathrm{ClCH}_{2} \mathrm{COONa}$ was successfully assembled on the surface of the membrane. The introduction of hydrophilic carboxyl groups led to this result. In addition to hydrophilicity, chargeability was also affected. The zeta potentials of the original PEI/TMA membrane and the modified membrane were analyzed (Figure 5). The original PEI/TMA membrane (M0) surface was highly positively charged, which was due to the highly protonated amino group. Sodium chloroacetate was easily ionized in aqueous solution to form negatively charged $\mathrm{CH}_{2} \mathrm{COO}^{-}$groups, while the amino groups on the PEI/TMA membrane surface were protonated and positively charged. After the PEI/TMA membrane was immersed in the sodium chloroacetate solution, by extending the immersing time (SI, Figure $\mathrm{S} 2$ ), the $\mathrm{CH}_{2} \mathrm{COO}^{-}$groups were gradually attracted to the membrane surface via electrostatic interaction. In addition, influenced by negatively charged carboxyl groups, the positively charged amino groups were effectively shielded, and the positive chargeability of the membrane surface was effectively reduced.

(a)

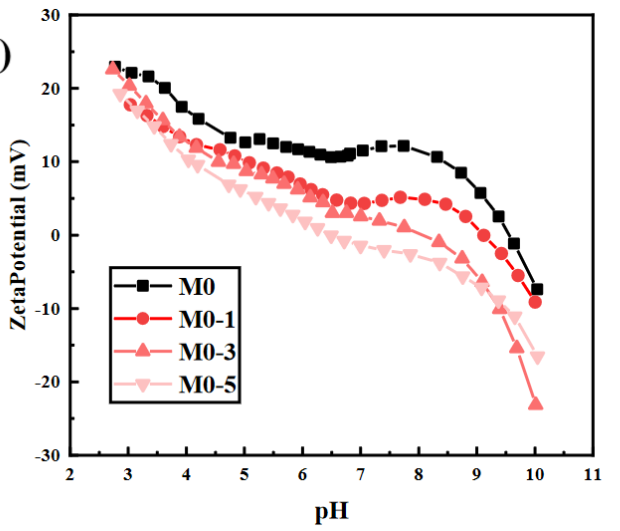

(b)

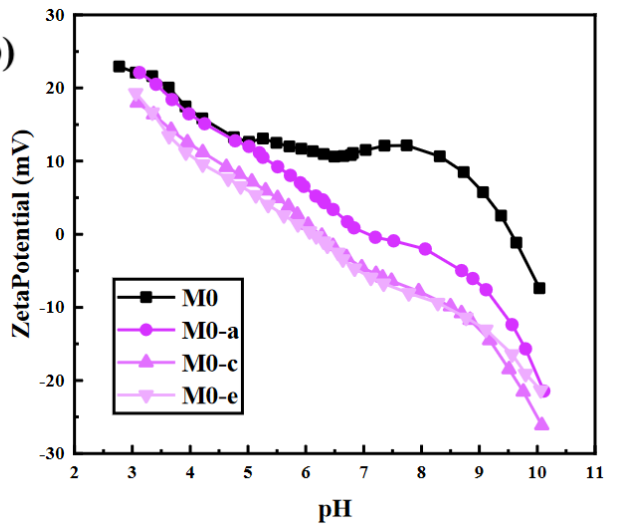

Figure 5. The influence of $\mathrm{ClCH}_{2} \mathrm{COONa}$ concentration (a) and modification time (b) on the zeta potential of the membrane surface.

\subsection{Membrane Desalination and Permeability Performance}

In the membrane performance test experiment (Figure 6), the PEI/TMA membrane exhibited a stable desalination performance. The rejection rate of the other three salts $(\mathrm{NaCl}$, $\mathrm{MgSO}_{4}, \mathrm{Na}_{2} \mathrm{SO}_{4}$ ) had also not changed much (SI, Figure S3). $\mathrm{ClCH}_{2} \mathrm{COONa}$ could not damage the membrane structure. The SEM images of the membrane surface also confirmed this (Figure 2). As the degree of modification deepened (high $\mathrm{ClCH}_{2} \mathrm{COONa}$ concentration and extension of modification time), water flux rose. In addition, the modification failed to change the molecular weight cut-off (MWCO) of the PEI/TMA membrane (SI, Figure S1). It could be believed that the increased flux was mainly caused by the hydrophilic surface and the neutralization of chargeability [34,35]. In the modification process, the increase 
in water flux was positively correlated with hydrophilicity (Figure 4). High wettability promoted rapid penetration of water molecules through the membrane. It is believed that the highly hydrophilic membrane surface has a strong antifouling ability [36,37]. This result showed that the modification process not only maintained the composite membrane structure, but the basic permeability of the membrane was also improved.

(a)

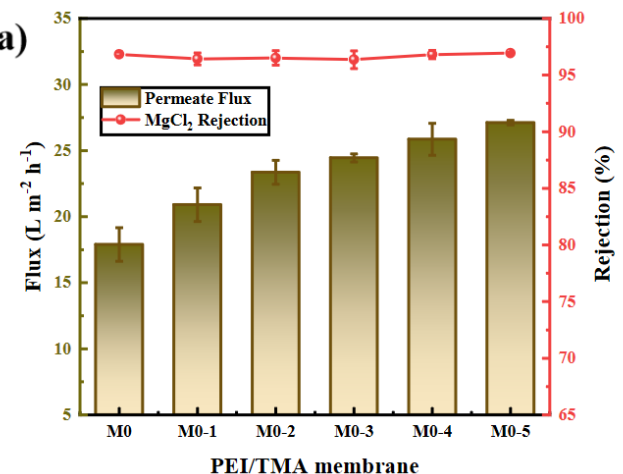

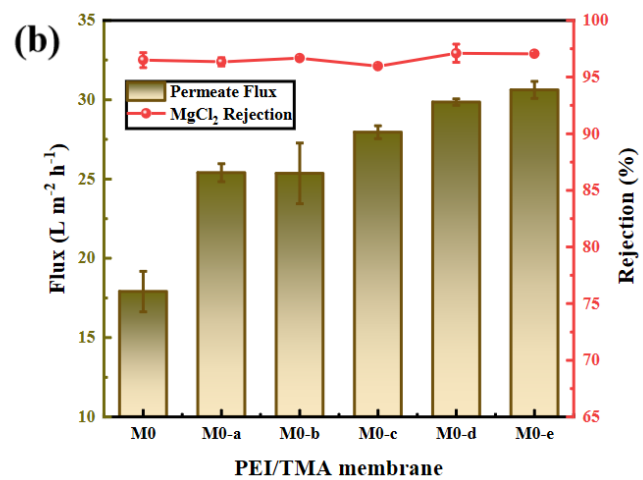

Figure 6. Separation and permeability performance of original membrane and modified membrane ((a), $\mathrm{ClCH}_{2} \mathrm{COONa}$ concentration; (b), modification time) to $500 \mathrm{ppm} \mathrm{MgCl}_{2}$ solution.

\subsection{Membrane Antifouling Test}

With the BSA solution (100 ppm, $\mathrm{pH}$ 6.0) as the pollution source, the antifouling experiment of the PEI/TMA membrane was carried out (Figure 7). In a short period of time, the PEI/TMA membrane flux dropped sharply, which was caused by BSA adsorption. The membrane surface was blocked and the transport of water molecules was hindered. In addition, during this period of time $(20 \mathrm{~min})$, the membrane surface adsorption reached saturation, and the pore plugging phenomenon did not deepen further. The flux did not continue to change too much (SI, Figure S4). After $\mathrm{ClCH}_{2} \mathrm{COONa}$ modification, the BSA pollution had been reduced and the initial flux of the membrane was improved. Increasing the $\mathrm{ClCH}_{2} \mathrm{COONa}$ concentration and extending the modification time could achieve better results. A high concentration of $\mathrm{ClCH}_{2} \mathrm{COONa}$ shielded as many amino sites as possible, which also led to a reduced zeta potential on the membrane surface. It was an effective way to reduce BSA adsorption from the charge effect.
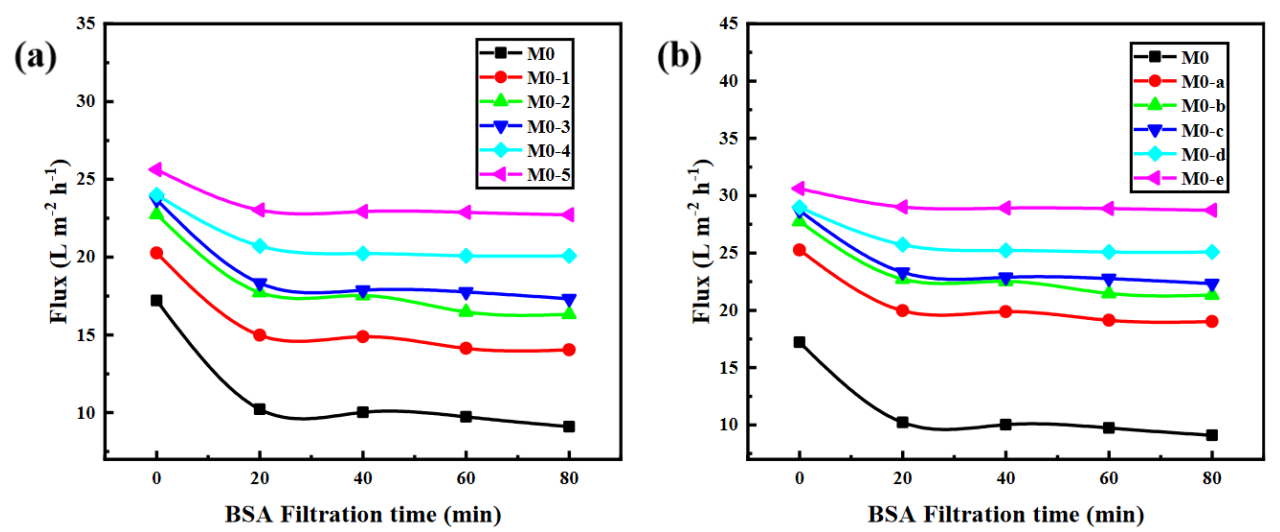

Figure 7. Antipollution test $\left((\mathbf{a}), \mathrm{ClCH}_{2} \mathrm{COONa}\right.$ concentration influence; (b), modification time influence) with BSA solution ( $\mathrm{pH}$ 6.0).

The improved hydrophilicity (Figure 4) promoted faster transportation of water molecules $[38,39]$. The membrane surface was more likely to form a hydration layer, which hindered the adsorption of BSA molecules. From the SEM image of the membrane surface after filtering the BSA, the adsorption phenomenon on the modified membrane surface was greatly reduced (SI, Figure S5). The reduction in the chargeability of the membrane 
surface was also a factor in the antipollution of the PEI/TMA membrane [40,41]. Due to the low isoelectric point of BSA (about 4.7), the high positive charge of the original membrane (M0) made the adsorption of BSA easy. After modification, a part of the protonated amino group was shielded [42-44] and the charge attraction was weakened between BSA and the membrane surface. Therefore, the blockage of the membrane pores was relieved. The drop rate of the flux had also been reduced (Figure 8). Hence, the modified membrane (M0-1 5, $\mathrm{M} 0-\mathrm{a} \sim \mathrm{e})$ showed higher water permeability and excellent antipollution ability. The best performance could be achieved after modification with $0.5 \%$ sodium chloroacetate for $10 \mathrm{~h}$, and the greater degree of modification hardly worked anymore (SI, Figure S6).
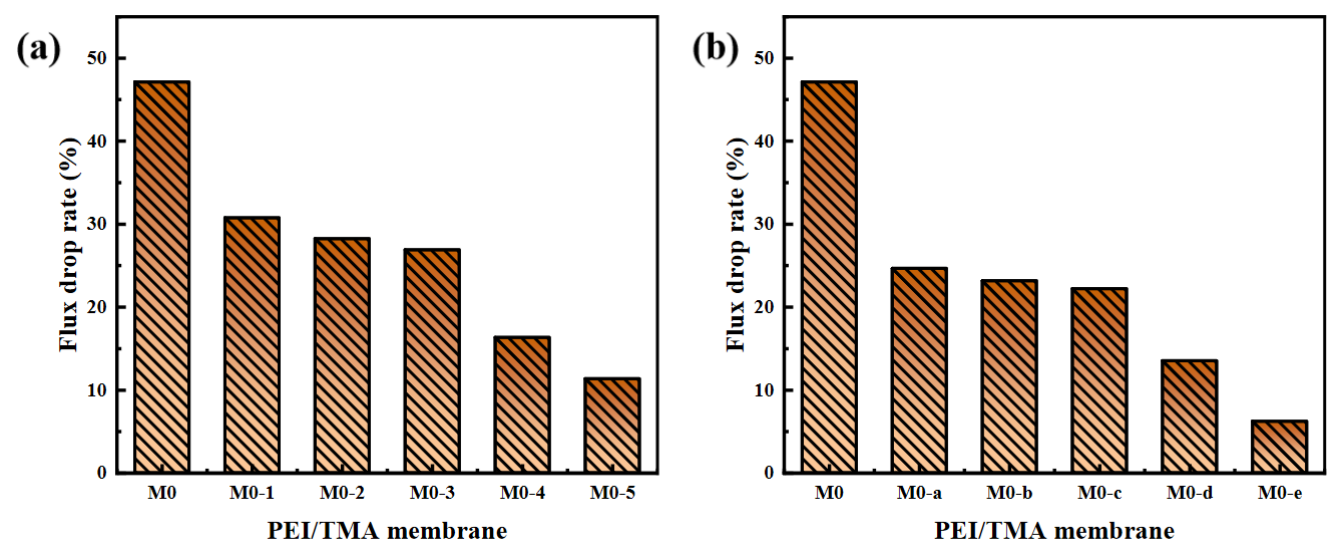

Figure 8. Flux drop rate after membrane fouling ((a), $\mathrm{ClCH}_{2} \mathrm{COONa}$ concentration influence; (b), modification time influence).

To further verify the pollution resistance of the membrane, the membrane, after filtering BSA, was washed with pure water and the water permeability was tested. After cleaning, the membrane flux recovered to a certain extent (Figure 9), but the degree of membrane flux recovery was not great. It was believed that the adsorbed BSA molecule on the membrane surface was difficult to wash. In addition to the dirt that was physically embedded in the membrane layer, the combination of BSA and the positively charged membrane surface was also powerful. Pure water cleaning could only play a minor role in these pollutions. Through the modification, the initial flux of the membrane and the flux after being polluted had both increased, but membrane fouling still existed. $\mathrm{ClCH}_{2} \mathrm{COONa}$ modification could only reduce but not completely eliminate BSA pollution. Hence, the flux could not be fully recovered.
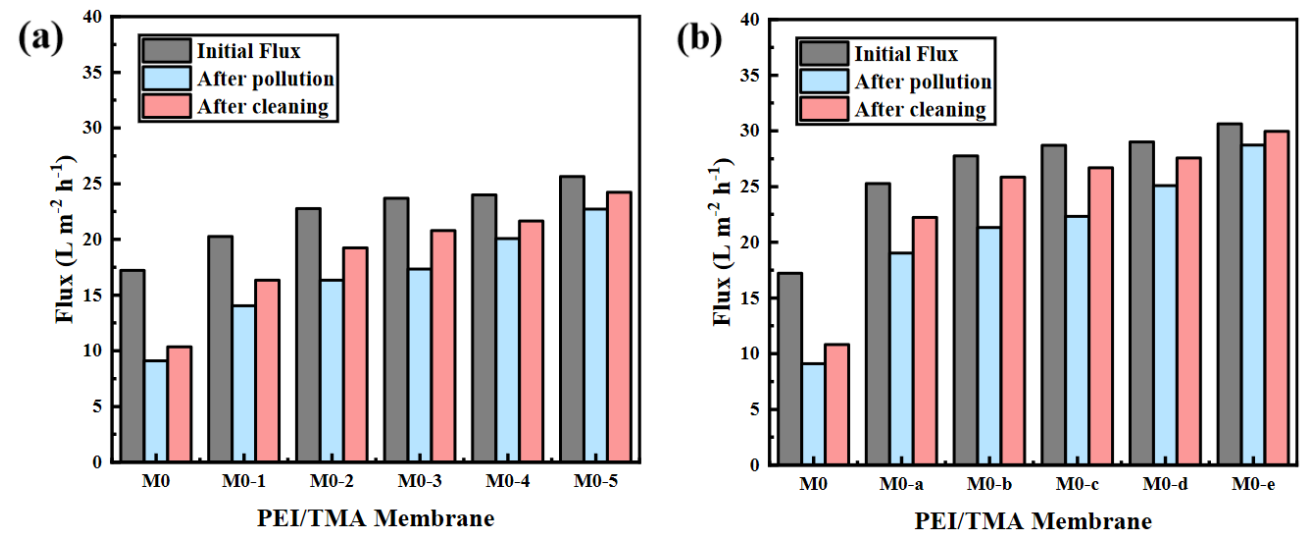

Figure 9. The change of membrane flux $\left((\mathbf{a}), \mathrm{ClCH}_{2} \mathrm{COONa}\right.$ concentration influence; (b) modification time influence) after $8 \mathrm{~h}$ of pure water cycle cleaning.

The acid and alkali environments affect the chargeability of the PEI/TMA membrane surface $[45,46]$, and thus the degree of contamination of the membrane surface by the 
protein. For the pH 3 BSA solution, the modified membrane still showed strong antipollution ability and high flux (Figure 10a,b). After the modified membrane was contaminated by BSA, the flux drop rate was effectively reduced (Figure 11a,b), and the lowest drop rate was only $6.2 \%$. In an acidic environment, the BSA molecule was positively charged and it was not easily adsorbed on the membrane surface due to charge repulsion $[47,48]$. Compared with the conventional test environment, the antipollution ability of the modified membrane was improved more obviously. On the contrary, $\mathrm{ClCH}_{2} \mathrm{COONa}$ modification slightly improved the antifouling performance of the PEI/TMA membrane in an alkaline environment (Figure 11c,d). Although the modification increased the initial permeability of the membrane, BSA still reduced the flux in a relatively short period of time (Figure 10c,d). Compared to a lower PH environment, the modification weakened the pollution process to a lesser degree. It was possible that $\mathrm{pH} 9$ was too close to the isoelectric point of the PEI/TMA membrane. Although the modification slightly reduced the positive charge of the membrane, the charge repulsion might not play much of a role in this test environment. Therefore, the adsorption of BSA had not been weakened too much. The modified membrane showed a better antifouling performance in a neutral or weak acid environment.
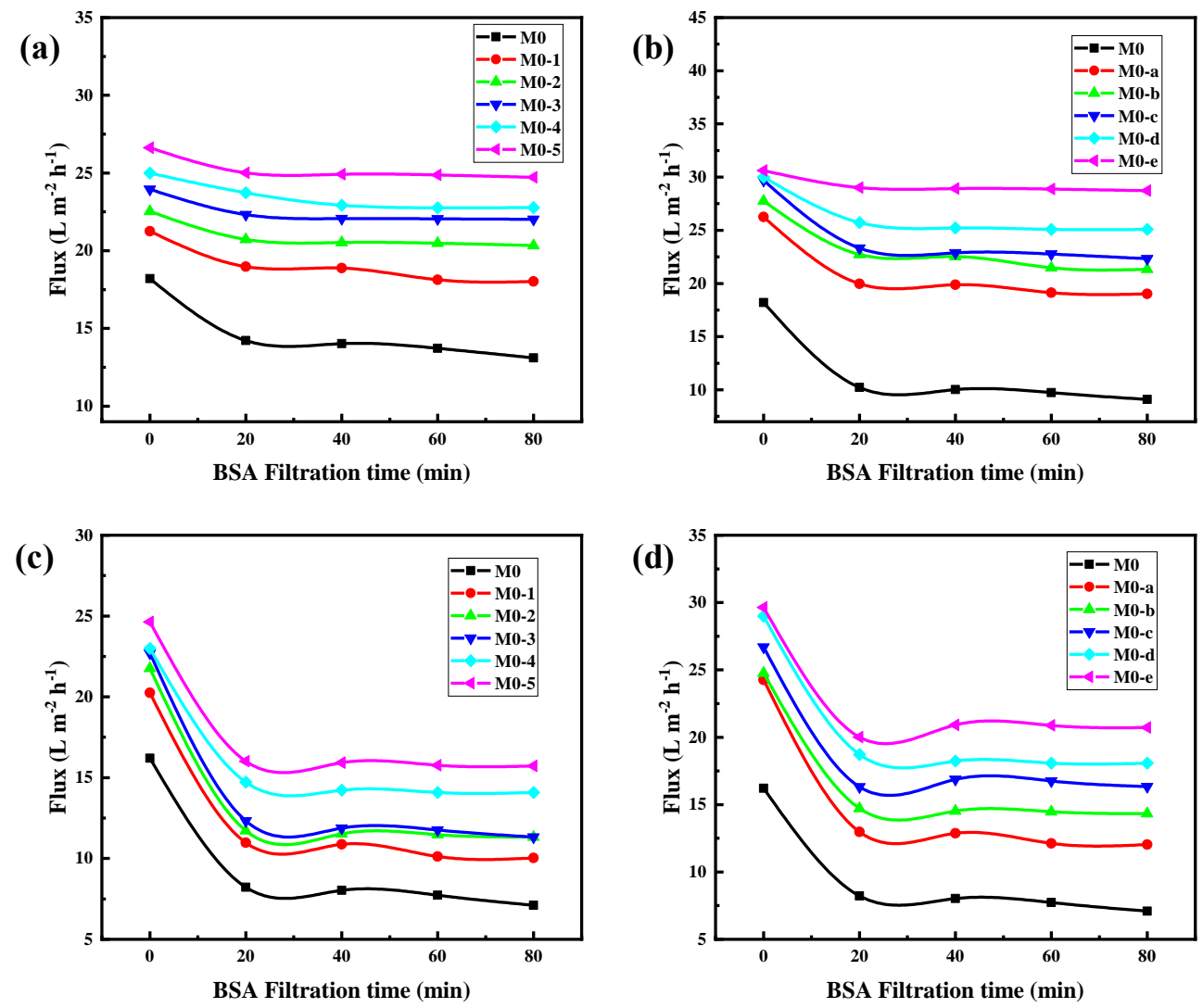

Figure 10. Antipollution test of membranes in acid ((a,b), 100 ppm BSA solution, pH 3) and alkali environments ((c,d), 100 ppm BSA, pH 9). 

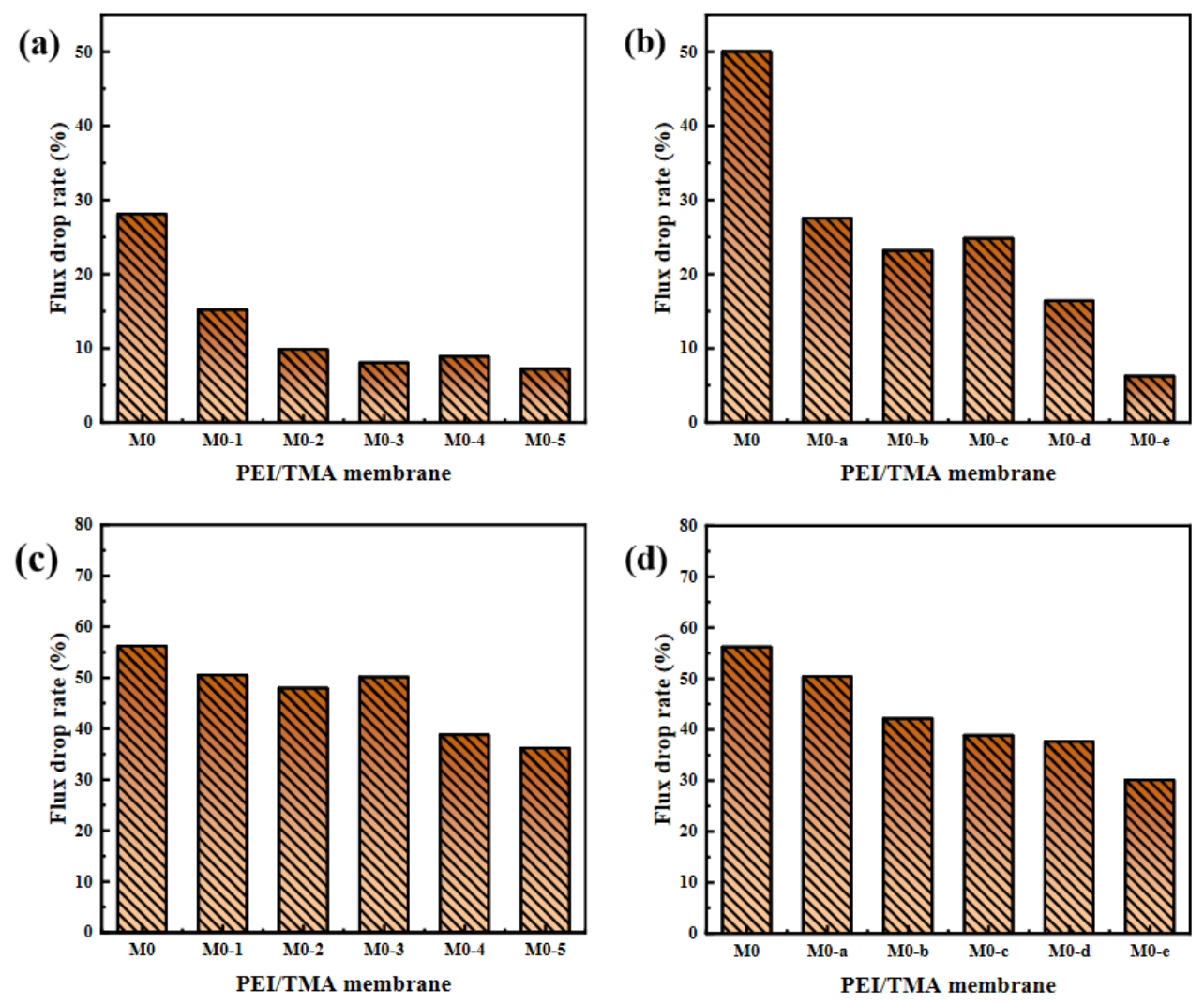

Figure 11. Flux drop rate of membranes in acid ((a,b), 100 ppm BSA solution, pH 3) and alkali environments ((c,d), 100 ppm BSA, pH 9).

\subsection{Performance Comparison}

In recent years, there has been more and more research on the preparation of PEI NF membranes. Some newly developed membranes were summarized in Table 2. Combined with this work, the performance of these membranes was compared and analyzed. The PEI/TMA membrane (M0-e) had unique advantages in the removal of $\mathrm{MgCl}_{2}$ while the flux reached a high level. In the treatment of water softening and cleaning water, PEI NF membranes could have a great treatment effect. Due to the susceptibility to pollution, the quality of the influent water in the NF process needed to be treated at the front end. High pollution-resistant NF membranes could reduce the cost of the water inlet front. The modified PEI/TMA NF membranes have such characteristics of resistance to BSA protein contamination, therefore it could have very practical application prospects in water softening and household water purification.

Table 2. Performance comparison with other PEI NF membranes.

\begin{tabular}{ccccc}
\hline Membrane & $\begin{array}{c}\text { Flux } \\
\left(\mathbf{L ~ m ~}^{-\mathbf{2}} \mathbf{~} \mathbf{~}^{\mathbf{- 1}} \mathbf{b a r}^{\mathbf{- 1}} \mathbf{)}\right.\end{array}$ & $\begin{array}{c}\text { Operating } \\
\text { Pressure (bar) }\end{array}$ & $\begin{array}{c}\mathbf{M g C l}_{\mathbf{2}} \\
\text { Rejection (\%) }\end{array}$ & Reference \\
\hline FPEI/PES & 1.1 & 6 & 39.3 & {$[49]$} \\
PEI/PDA-PAN & 2.4 & 8 & 92.4 & {$[50]$} \\
PEI-TA/PES & 40.6 & 4 & 9.6 & {$[51]$} \\
PEI/C-PES & 10.1 & 2 & 90 & {$[52]$} \\
PS28-Na05-P085 & 7.4 & 5.5 & 93.3 & {$[53]$} \\
PEI/TMA M0-e & 15 & 2 & 96 & This work \\
\hline
\end{tabular}

\section{Conclusions}

In this work, the PEI/TMA membrane was modified by $\mathrm{ClCH}_{2} \mathrm{COONa}$ through charge action. The modified membrane had higher water flux and pollution resistance. The 
modification concentration and time were discussed in detail. The membrane structure was not damaged and the initial desalination performance was maintained. Due to the improvement of hydrophilicity and chargeability, the membrane flux had been improved and the degree of BSA contamination had been effectively alleviated. The initial flux of the PEI/TMA membrane increased from $17.2 \mathrm{~L} \mathrm{~m}^{-2} \mathrm{~h}^{-1}$ to $30 \mathrm{~L} \mathrm{~m}^{-2} \mathrm{~h}^{-1}$. After filtering the BSA solution, the flux drop rate of the modified membrane under the optimal conditions $\left(0.5 \% \mathrm{ClCH}_{2} \mathrm{COONa}, 10 \mathrm{~h}\right)$ was only $6.2 \%$. Through this surface modification, the PEI/TMA membrane could achieve a great antipollution effect. It will be beneficial to promote the application of the PEI/TMA membrane in related fields such as protein concentration.

Supplementary Materials: The following are available online at https://www.mdpi.com/article/10 .3390/membranes11090705/s1, Figure S1: Molecular weight PEG removal rate curves of membrane M0-d, Figure S2: XPS O element narrow spectrum analysis on the surface of original membrane and modified membrane, Figure $\mathrm{S} 3: \mathrm{NaCl}, \mathrm{MgSO}_{4}, \mathrm{Na}_{2} \mathrm{SO}_{4}$ rejection rate of modified membranes, Figure S4: Anti-pollution test after 80 minutes, Figure S5: Comparison of M0 and M0-e before and after filtering BSA solution, Figure S5: BSA anti-fouling test for modified membranes with higher concentration of sodium chloroacetate (a) and longer modification time (b).

Author Contributions: Writing-original draft: K.G.; Validation: S.P.; Conceptualization: Y.Z.; Resources: C.G. All authors have read and agreed to the published version of the manuscript.

Funding: This work has been strongly supported by Provincial Key R\&D Program of Zhejiang Province (Grant No. 2021C01173).

Institutional Review Board Statement: Not applicable.

Data Availability Statement: Data are available on request.

Acknowledgments: Thanks to the scientific research conditions created by Center for Membrane and Water Science \& Technology.

Conflicts of Interest: The authors declare no conflict of interest.

\section{References}

1. Oatley-Radcliffe, D.L.; Walters, M.; Ainscough, T.J.; Williams, P.M.; Mohammad, A.W.; Hilal, N. Nanofiltration membranes and processes: A review of research trends over the past decade. J. Water Process. Eng. 2017, 19, 164-171. [CrossRef]

2. Shao, G.; Liu, Y.; Yong, J. Experimental study on near zero discharge of desulphurization wastewater treated with nanofiltration membrane. Membr. Sci. Technol. 2019, 39, 124-128.

3. Zhang, H.; He, Q.; Luo, J.; Wan, Y.; Darling, S.B. Sharpening Nanofiltration: Strategies for Enhanced Membrane Selectivity. ACS Appl. Mater. Interfaces 2020, 12, 39948-39966. [CrossRef]

4. Wei, Y.; Wu, H. A Pilot Study on Membrane Fouling in the Treatment of Taihu Lake Water by Nanofiltration. China Water Wastewater 2021, 37, 66-70.

5. Abdelhamid, A.E.; El-Sayed, A.A.; Khalil, A.M. Polysulfone nanofiltration membranes enriched with functionalized graphene oxide for dye removal from wastewater. J. Polym. Eng. 2020, 40, 833-841. [CrossRef]

6. $\quad$ Dlamini, D.S.; Matindi, C.; Vilakati, G.D.; Tesha, J.M.; Motsa, M.M.; Thwala, J.M.; Mamba, B.B.; Hoek, E.M.V.; Li, J. Fine-tuning the architecture of loose nanofiltration membrane for improved water flux, dye rejection and dye/salt selective separation. $J$. Membr. Sci. 2021, 621, 118930. [CrossRef]

7. Yang, S.; Wang, J.; Fang, L.; Lin, H.; Liu, F.; Tang, C.Y. Electrosprayed polyamide nanofiltration membrane with intercalated structure for controllable structure manipulation and enhanced separation performance. J. Membr. Sci. 2020, 602, 117971. [CrossRef]

8. Si, Z.; Wang, Z.; Cai, D.; Li, G.; Li, S.; Qin, P. A high-permeance organic solvent nanofiltration membrane via covalently bonding mesoporous MCM-41 with polyimide. Sep. Purif. Technol. 2020, 241, 116545. [CrossRef]

9. Fu, J.; Pang, B.; Jin, X.; Yu, P. Efficiency Analysis and Membrane Regeneration of Tail Water Treatment in Wastewater Treatment Plant by Double Membrane Method. China Water Wastewater 2020, 36, 98-103.

10. Elakkiya, S.; Arthanareeswaran, G.; Ismail, A.F.; Goh, P.S.; Thuyavan, L.Y. Review on characteristics of biomaterial and nanomaterials based polymeric nanocomposite membranes for seawater treatment application. Environ. Res. 2021, $197,111177$.

11. Tsui, T.H.; Ekama, G.A.; Chen, G.H. Quantitative characterization and analysis of granule transformations: Role of intermittent gas sparging in a super high-rate anaerobic system. Water Res. 2018, 139, 177-186. [CrossRef]

12. Tsui, T.H.; Chen, L.; Hao, T.; Chen, G.H. A super high-rate sulfidogenic system for saline sewage treatment. Water Res. 2016, 104, 147-155. [CrossRef] [PubMed] 
13. Wang, S.; Wang, Z.-Y.; Xia, J.-Z.; Wang, X.-M. Polyethylene-supported nanofiltration membrane with in situ formed surface patterns of millimeter size in resisting fouling. J. Membr. Sci. 2021, 620, 118830. [CrossRef]

14. Ren, L.; Chen, J.; Lu, Q.; Han, J.; Wu, H. Anti-biofouling nanofiltration membrane constructed by in-situ photo-grafting bactericidal and hydrophilic polymers. J. Membr. Sci. 2021, 617, 118658. [CrossRef]

15. Guo, Y.; Li, T.Y.; Xiao, K.; Wang, X.M.; Xie, Y.F. Key foulants and their interactive effect in organic fouling of nanofiltration membranes. J. Membr. Sci. 2020, 610, 118252. [CrossRef]

16. Ngo, M.T.T.; Ueyama, T.; Makabe, R.; Bui, X.T.; Nghiem, L.D.; Nga, T.T.V.; Fujioka, T. Fouling behavior and performance of a submerged flat-sheet nanofiltration membrane system for direct treatment of secondary wastewater effluent. J Water Process. Eng. 2021, 41, 101991. [CrossRef]

17. Zhao, D.; Liu, J.; Qiu, L.; Xu, J.; Jiang, G.; Xue, T.; Wang, B.; Gu, Z.; Liu, G. Roles of a mixed hydrophilic/hydrophobic interface in the regulation of nanofiltration membrane fouling in oily produced wastewater treatment: Performance and interfacial thermodynamic mechanisms. Sep. Purif. Technol. 2021, 257, 117970. [CrossRef]

18. Jun, B.M.; Cho, J.; Jang, A.; Chon, K.; Westerhoff, P.; Yoon, Y.; Rho, H. Charge characteristics (surface charge vs. zeta potential) of membrane surfaces to assess the salt rejection behavior of nanofiltration membranes. Sep. Purif. Technol. 2020, 247, 117026. [CrossRef]

19. Rho, H.; Cho, J.; Westerhoff, P.; Chon, K. Intrinsic pKa of Nanofiltration Membrane Surfaces to Assess Fouling and Cleaning Behaviors Induced by Foulant-Membrane Electrostatic Interactions. Environ. Sci. Technol. 2020, 54, 7706-7714. [CrossRef]

20. Song, Y.; Li, X.; Li, C.; Li, J.; Dong, Z.; Zhang, M.; Qi, P.; Bai, X.; Jiang, K. Exploring and comparing the roles of Ca ${ }^{2+}$ and Mg ${ }^{2+}$ in small-sized natural organics-induced charged nanofiltration membrane fouling. Sep. Purif. Technol. 2020, 251, 117415. [CrossRef]

21. Guo, Z.; Zhang, K.; Guan, H.; Liu, M.; Yu, S.; Gao, C. Improved separation efficiency of polyamide-based composite nanofiltration membrane by surface modification using 3-aminopropyltriethoxysilane. Sep. Purif. Technol. 2021, 274, 119142. [CrossRef]

22. Zhan, Z.M.; Tang, Y.J.; Zhu, K.K.; Xue, S.M.; Ji, C.H.; Tang, C.Y.; Xu, Z.L. Coupling heat curing and surface modification for the fabrication of high permselectivity polyamide nanofiltration membranes. J. Membr. Sci. 2021, 623, 119073. [CrossRef]

23. El Meragawi, S.; Akbari, A.; Hernandez, S.; Mirshekarloo, M.S.; Bhattacharyya, D.; Tanksale, A.; Majumder, M. Enhanced permselective separation of per-fluorooctanoic acid in graphene oxide membranes by a simple PEI modification. J. Mater. Chem. A 2020, 8, 24800-24811. [CrossRef]

24. Li, T.; Xiao, Y.; Guo, D.; Shen, L.; Li, R.; Jiao, Y.; Xu, Y.; Lin, H. In-situ coating TiO(2 )surface by plant-inspired tannic acid for fabrication of thin film nanocomposite nanofiltration membranes toward enhanced separation and antibacterial performance. $J$. Colloid Interface Sci. 2020, 572, 114-121. [CrossRef] [PubMed]

25. Hosseini, S.M.; Moradi, F.; Farahani, S.K.; Bandehali, S.; Parvizian, F.; Ebrahimi, M.; Shen, J. Carbon nanofibers/chitosan nanocomposite thin film for surface modification of poly(ether sulphone) nanofiltration membrane. Mater. Chem. Phys. 2021, 269, 124720. [CrossRef]

26. Saffarimiandoab, F.; Gul, B.Y.; Tasdemir, R.S.; Ilter, S.E.; Unal, S.; Tunaboylu, B.; Menceloglu, Y.Z.; Koyuncu, I. A review on membrane fouling: Membrane modification. Desalin. Water Treat. 2021, 216, 47-70. [CrossRef]

27. Zheng, J.; Li, M.; Yu, K.; Hu, J.; Zhang, X.; Wang, L. Sulfonated multiwall carbon nanotubes assisted thin-film nanocomposite membrane with enhanced water flux and anti-fouling property. J. Membr. Sci. 2017, 524, 344-353. [CrossRef]

28. Gu, K.; Wang, S.; Li, Y.; Zhao, X.; Zhou, Y.; Gao, C. A facile preparation of positively charged composite nanofiltration membrane with high selectivity and permeability. J. Membr. Sci. 2019, 581, 214-223. [CrossRef]

29. Guo, M.; Wang, S.; Gu, K.; Song, X.; Zhou, Y.; Gao, C. Gradient cross-linked structure: Towards superior PVA nanofiltration membrane performance. J. Membr. Sci. 2019, 569, 83-90. [CrossRef]

30. Abu Seman, M.N.; Johnson, D.; Al-Malek, S.; Hilal, N. Surface modification of nanofiltration membrane for reduction of membrane fouling. Desalin. Water Treat. 2009, 10, 298-305. [CrossRef]

31. Abu Seman, M.N.; Khayet, M.; Bin Ali, Z.I.; Hilal, N. Reduction of nanofiltration membrane fouling by UV-initiated graft polymerization technique. J. Membr. Sci. 2010, 355, 133-141. [CrossRef]

32. Wang, Y.; Lyu, Z.; Jiang, P.; Yu, S. Constructing high permeable and anti-fouling coating layer on surface of polyamide thin-film composite membrane. Membr. Sci. Technol. 2020, 40, 31-36.

33. Xiang, S.; Yang, J.; Cui, Z.; Qin, S.; Qin, Q. Preparation of hollow fiber membrane via grafting tannic acid and its influence on microstructure, permeability and anti-fouling. Mater. Lett. 2021, 285, 129095. [CrossRef]

34. Li, H.; Liu, G.; Che, Z.; Chen, J.; Guo, C.; Lu, J. Study on Hydrophilic Modification of PTFE Hollow Fiber Membrane by Mineralization. China Plast. Ind. 2020, 48, 152-155.

35. Dobosz, K.M.; Kuo-Leblanc, C.A.; Bowden, J.W.; Schiffman, J.D. Robust, Small Diameter Hydrophilic Nanofibers Improve the Flux of Ultrafiltration Membranes. Ind. Eng. Chem. Res. 2021, 60, 9179-9188. [CrossRef]

36. Hu, H.; Dong, J.; Lin, X. Surface hydrophilic modification of brominated poly(phenylene oxide) ultrafiltration membrane. Membr. Sci. Technol. 2020, 40, 22-29.

37. Zhou, M.; Chen, J.; Zhou, W.; Sun, J.; Tang, H. Developing composite nanofiltration membranes with highly stable antifouling property based on hydrophilic roughness. Sep. Purif. Technol. 2021, 256, 117799. [CrossRef]

38. Bai, L.; Wu, H.; Ding, J.; Ding, A.; Zhang, X.; Ren, N.; Li, G.; Liang, H. Cellulose nanocrystal-blended polyethersulfone membranes for enhanced removal of natural organic matter and alleviation of membrane fouling. Chem. Eng. J. 2020, 382, 122919. [CrossRef] 
39. Lyly, L.H.T.; Ooi, B.S.; Lim, J.K.; Derek, C.J.C.; Low, S.C. Correlating the membrane surface energy to the organic fouling and wetting of membrane distillation at elevated temperature. J. Environ. Chem. Eng. 2021, 9, 104627. [CrossRef]

40. Bao, X.; She, Q.; Long, W.; Wu, Q. Ammonium ultra-selective membranes for wastewater treatment and nutrient enrichment: Interplay of surface charge and hydrophilicity on fouling propensity and ammonium rejection. Water Res. 2021, 190, 116678. [CrossRef] [PubMed]

41. Lay, H.T.; Wang, R.; Chew, J.W. Membrane fouling by mixtures of oppositely charged particles. J. Membr. Sci. 2021, 625, 119093. [CrossRef]

42. Duznovic, I.; Diefenbach, M.; Ali, M.; Stein, T.; Biesalski, M.; Ensinger, W. Automated measuring of mass transport through synthetic nanochannels functionalized with polyelectrolyte porous networks. J. Membr. Sci. 2019, 591, 117344. [CrossRef]

43. Feiyang, X.; Dong, W.; Kun, Y. Electrodeposition Assisted Dynamic Assemblies of Chitosan/Alginate Composite Multi-Membrane. IOP Conf. Ser. Mater. Sci. Eng. 2020, 774, 012049.

44. Zhang, J.; Jia, R.; Li, S.; Su, B. Preparation and properties of covalent layer-by-layer self-assembly nanofiltration membranes. Membr. Sci. Technol. 2020, 40, 139-147.

45. Moradi, G.; Zinadini, S.; Rajabi, L. Development of nanofiltration PES membranes incorporated with hydrophilic para hydroxybenzoate alumoxane filler for high flux and antifouling property. Chem. Eng. Res. Des. 2020, 158, 148-163. [CrossRef]

46. Pino-Soto, L.; Schwarz, A.; Vargas, C.; Saravia, F.; Horn, H.; Borquez, R. Influence of multivalent-electrolyte metal solutions on the superficial properties and performance of a polyamide nanofiltration membrane. Sep. Purif. Technol. 2021, 272, 118846. [CrossRef]

47. Susanto, H.; Julyanti, D.P.; Roihatin, A. Synthesis of Low Fouling Porous Polymeric Membranes. Adv. Mater. Res. 2014, 896, 7-19. [CrossRef]

48. Jiang, S.; Li, Y.; Ladewig, B.P. A review of reverse osmosis membrane fouling and control strategies. Sci. Total Environ. 2017, 595, 567-583. [CrossRef]

49. Qian, Y.; Wu, H.; Sun, S.P.; Xing, W. Perfluoro-functionalized polyethyleneimine that enhances antifouling property of nanofiltration membranes. J. Membr. Sci. 2020, 611, 118286. [CrossRef]

50. Yang, Z.; Huang, X.; Wang, J.; Tang, C.Y. Novel polyethyleneimine/TMC-based nanofiltration membrane prepared on a polydopamine coated substrate. Front. Chem. Sci. Eng. 2018, 12, 273-282. [CrossRef]

51. Li, Q.; Liao, Z.; Fang, X.; Wang, D.; Xie, J.; Sun, X.; Wang, L.; Li, J. Tannic acid-polyethyleneimine crosslinked loose nanofiltration membrane for dye/salt mixture separation. J. Membr. Sci. 2019, 584, 324-332. [CrossRef]

52. Zarei, F.; Moattari, R.M.; Rajabzadeh, S.; Bagheri, M.; Taghizadeh, A.; Mohammadi, T.; Matsuyama, H. Preparation of thin film composite nano-filtration membranes for brackish water softening based on the reaction between functionalized UF membranes and polyethyleneimine. J. Membr. Sci. 2019, 588, 117207. [CrossRef]

53. Shen, Q.; Xu, S.J.; Dong, Z.Q.; Zhang, H.Z.; Xu, Z.L.; Tang, C.Y. Polyethyleneimine modified carbohydrate doped thin film composite nanofiltration membrane for purification of drinking water. J. Membr. Sci. 2020, 610, 118220. [CrossRef] 